\title{
Modernization of Agrarian Economy in the Republic of Kazakhstan
}

\author{
Gulnara K. Kurmanova1, Bibigul B. Sukhanberdina ${ }^{1 *}$, Bakit A. Urazova1 \\ ${ }^{1}$ West Kazakhstan Innovative-technological University, N. Nazarbayev Ave. 194, 090000, \\ Uralsk, Kazakhstan
}

\begin{abstract}
In this article we study what the concept of «modernization» in the agricultural economy entails. Thanks to modernization, the agricultural economy is becoming more efficient based on a new development model. The analysis of the modernization of the agricultural economy is important for understanding the development of the country. And if, in general, the process of modernization in modern Kazakhstan is quite actively studied by specialists, then the chosen aspect-the modernization of the agricultural economy-is poorly studied in domestic science. The study of the agricultural sector in the context of modernization allows us to substantiate conclusions and practical proposals for improving the dynamic development of agriculture and achieving a new quality of life for the rural population. The concept of «modernization of the agricultural economy» is clarified as a multi-faceted process of complex innovations carried out by subjects of both the agricultural economy and industrial subjects, which ensures the transition to a new level of crop productivity and productivity of farm animals. Modernization of the agricultural economy is identical to economic investment. The financial resources in the process of modernization providing and generating are investments. The research logic reflects the author's view of the modern concept of modernization in the agrarian economy, considering the integration between development and modernization into a new format. The starting point of this scientific article is the determination of the role and place of modernization in agriculture to ensure food security and independence of the Republic of Kazakhstan.
\end{abstract}

Keywords: modernization, agrarian economy, agricultural industry, progress, change, call, innovations.

For citation: Kurmanova, G.K., Sukhanberdina, B.B. \& Urazova, B.A. (2021). Modernization of Agrarian Economy in the Republic of Kazakhstan. Economics: the Strategy and Practice, 16(3), 35-50, https://doi.org/10.51176/19979967-2021-3-35-50

* Corresponding author: Bibigul B. Sukhanberdina - Candidate of Economic Sciences, Associate Professor of the Department of Accounting and Finance, West Kazakhstan Innovative-technological University, Uralsk, N. Nazarbayev Ave. 194, 090000, + 7074309351, e-mail: suhanb@mail.ru.

Conflict of interests: the authors declare that there is no conflict of interest.

Financial support: The study was not sponsored (own resources).

The article received: 07.04 .2021

The article approved for publication: 25.05 .2021

Date of publication: 30.09 .2021 


\title{
REGIONAL ECONOMY AND TERRITORIAL DEVELOPMENT
}

\section{Қазақстан Республикасында аграрлық экономиканы жаңғырту}

\author{
Курманова Г.К. ${ }^{1}$, Суханбердина Б.Б. ${ }^{*}$, Уразова Б.А. ${ }^{1}$ \\ ${ }^{\prime}$ Батыс Қазақстан инноваииялық-технологиялық университеті, \\ Н.Назарбаев д., 194, 090000, Орал, Қазақстан
}

\section{Түйін}

Мақалада авторлар аграрлық экономикадағы «модернизация» ұғымының мазмұнын зерттеді. Жаңғырту аграрлық экономика дегеніміз авторлары жаңалық ретінде ерекшеленетін кешенділігімен және мультипликативтік әсері үшін сабақтас салалардың. Аграрлық экономика жаңғыртудың арқасында дамудың жаңа моделінің негізінде неғұрлым жоғары деңгейге ие болады. Аграрлық экономиканы жаңғыртуды талдау елдің үдемелі дамуы үшін өзінің маңыздылығы арқасында өзекті болып табылады. Егер тұтастай алғанда, қазіргі Қазақстандағы жаңғырту процесін мамандар белсенді зерттеп жатса, онда таңдалған аспект - аграрлық экономиканы жаңғырту-отандық ғылымда нашар зерттелген. Жаңғырту жағдайында аграрлық саланы зерттеу ауыл шаруашылығының серпінді дамуын арттыру және ауыл халқының өмір сүруінің жаңа сапасына қол жеткізу бойынша тұжырымдар мен практикалық ұсыныстарды негіздеуге мүмкіндік береді. Ауыл шаруашылығы экономикасының субъектілері де, өнеркәсіп субъектілері де жүзеге асыратын кешенді сипаттағы жаңашылдықтардың көпқырлы процесі ретінде «аграрлық экономиканы жаңғырту» ұғымы нақтыланды, Бұл ауыл шаруашылығы дақылдарының шығымдылығы мен ауыл шаруашылығы жануарларының өнімділігінің жаңа деңгейіне көшуді қамтамасыз етеді. Аграрлық экономиканы жаңғырту экономикалық инвестицияларға ұқсас. Себебі жаңғыртуды қамтамасыз ету мен генерациялауда қаржы ресурстары инвестициялар болып табылады. Талданып отырған мәселені зерттеу логикасы даму мен модернизацияның жаңа форматқа кірігуін ескере отырып, аграрлық экономиканы жаңғыртудың қазіргі заманғы тұжырымдамасына автордың көзқарасын көрсетеді. Қазақстан Республикасының азық-түлік қауіпсіздігі мен тәуелсіздігін қамтамасыз ету үшін ауыл шаруашылығындағы жаңғыртудың рөлі мен орнын айқындау ғылыми мақаланың бастапқы тармағы болып табылады.

Түйін сөздер: жаңғырту, аграрлық экономика, ауыл шаруашылығы, прогресс, өзгерістер, қоңырау шалу, инновациялар.

Дәйексөз алу үшін: Курманова Г.К., Суханбердина Б.Б., Уразова Б.А. (2021). Қазақстан Республикасында аграрлық экономиканы жаңғырту. Экономика: стратегия және практика, 16(3), 35-50, https://doi.,org/10.51176/1997-9967-2021-3-35-50

* Хат-хабаршы авторы: Суханбердина Бибигуль Батыркаировна - э.ғ.к., «Есеп және қаржы» кафедрасының доценті,Батыс Қазақстан инновациялық-технологиялық университеті, Орал, Н. Назарбаев даңғылы 194, 090000, +87074309351, e-mail: suhanb@mail.ru.

Мүдделер қақтығысы: авторлар мүдделер қақтығысының жоқтығын мәлімдейді.

Қаржыландыру. Зерттеу демеушілік қолдау көрсеткен жоқ (меншікті ресурстар).

Мақала редакцияға түсті: 07.04.2021

Жариялау туралы шешім қабылданды: 25.05.2021

Жарияланды: 30.09.2021 


\title{
Модернизация аграрной экономики в Республике Казахстан
}

\author{
Курманова Г.К. ${ }^{1}$, Суханбердина Б.Б. ${ }^{*}$, Уразова Б.А. ${ }^{1}$ \\ 1 Западно-Казахстанский инновационно-технологический университет, \\ пр. Н.Назарбаева, 194, 090000, г.Уральск, Казахстан
}

\begin{abstract}
Аннотация
В статье авторами исследовано содержание понятия «модернизация» в аграрной экономике. Модернизация аграрной экономики понимается авторами как нововведения, отличающиеся комплексностью и мультипликативным эффектом для смежных отраслей. Аграрная экономика благодаря модернизации обретает более высокий уровень на основе новой модели развития. Анализ модернизации аграрной экономики является актуальным благодаря своей значимости для прогрессивного развития страны. И если в целом процесс модернизации в современном Казахстане довольно активно изучается специалистами, то избранный аспект - модернизация аграрной экономики - слабо исследован в отечественной науке. Исследование аграрной сферы в условиях модернизации позволяет обосновать выводы и практические предложения по повышению динамичного развития сельского хозяйства и достижению нового качества жизни сельского населения. Уточнено понятие «модернизация аграрной экономики» как многогранного процесса нововведений комплексного характера, осуществляемых субъектами как экономики сельского хозяйства так и субъектами промышленности, что обеспечивает переход на новый уровень урожайности сельскохозяйственных культур и продуктивности сельскохозяйственных животных. Модернизация аграрной экономики тождественна экономическим инвестициям. Так как финансовыми ресурсами в обеспечении и генерировании модернизации являются инвестиции. Логика исследования анализируемого вопроса отражает авторский взгляд на современную концепцию модернизации аграрной экономики с учетом интеграции развития и модернизации в новый формат. Исходным пунктом научной статьи является определение роли и места модернизации в сельском хозяйстве для обеспечения продовольственной безопасности и независимости Республики Казахстан.
\end{abstract}

Ключевые слова: модернизация, аграрная экономика, сельское хозяйство, прогресс, перемены, вызов, инновации.

Для цитирования: Курманова Г.К., СуханбердинаБ.Б., Уразова Б.А.(2021). Модернизация аграрной экономики в Республике Казахстан. Экономика: стратегия и практика, 16(3), 35-50, https://doi.org/10.51176/1997-9967$\underline{2021-3-35-50}$

* Корреспондирующий автор: Суханбердина Бибигуль Батыркаировна - кандидат экономических наук, доцент кафедры Учет и финансы, Западно-Казахстанский инновационно-технологический университет, г.Уральск, пр. Н. Назарбаева 194, 090000, +87074309351, e-mail: suhanb@,mail.ru.

Конфликт интересов: авторы заявляют об отсутствии конфликта интересов.

Финансирование. Исследование не имело спонсорской поддержки (собственные ресурсы).

Статья поступила в редакцию: 07.04 .2021

Принято решение о публикации: 25.05 .2021

Опубликовано: 30.09 .2021 


\section{Introduction}

Modernization (Greek «moderne» - the newest) is the ability of people to scientifically implement changes in society. The theory of modernization was substantiated by the sociologist M. Weber [1]. The theorist argued that a society moves from being archaic to being modern in the process of economic development of states. According to Weber, modernization is the abandonment of a traditional society based on custom in favor of a society based on performance. Economic theory considers the transition from a formation where tradition is of greater value than progressive development to a progressive socio-economic formation. This is the theory of modernization. Traditional (pre-industrial) is a society built on manual labor, primitive technologies. It contains innovations if they do not conflict with tradition. Whereas industrial (industrial, post-industrial) society provides economic growth through innovation. Traditions in this society are present and supported only if they do not hinder progress.

In a narrow sense, modernization is understood as a transformation from a pre-industrial to an industrial society, in a broad sense - innovation, progress, growth. Primary modernization essentially coincides with modernization in the narrow sense. Secondary modernization is the transition from an industrial society to a knowledge society. A qualitatively new reality has now emerged - the knowledge-based economy. reforms:

There are two methods for implementing

- dirigisme. The basis is the theory of state planning. The state actively manages the economy - "modernization from above";

- institutionalism. An institutional environment is being created in society. It motivates long-term economic growth. For Kazakhstan, which is implementing modernization in all areas, incl. in the agrarian, institutional, regional levels, the legal environment is changing based on current processes throughout the country. The state has adopted a number of regulatory documents, including the State Program for the Development of the Agro-Industrial Complex of the Republic of Kazakhstan for 2017-2021, Agribusiness-2020, the Law of the Republic of Kazakhstan «On State Regulation of the Development of the AgroIndustrial Complex and Rural Areas.» Institutional prerequisites are being formed, incl. a progressive ownership structure, an attractive investment climate, and conditions for innovation have been created. These directions also take place in the agrarian economy.

All spheres of Kazakhstani society are affected by modernization. This is the country's development strategy, a characteristic of the ongoing processes. The criterion for assessing the management of the modernization of the economy is a stable growth of macroeconomic indicators (GNP, employment, labor productivity, wages, national currency exchange rate).

The purpose of the study is to carry out a conceptual analysis of the modernization of the agrarian economy.

\section{Literature review}

To understand the trends prevailing in the scientific literature, we will analyze the definitions of various authors about modernization, highlighting the main characteristic of the studied category.

The essence of modernization, as noted by Yu.Wucherpfennig and F.Deutsch [2], is manifested through social conditions. The same approach is applied in the works of Ward R. [3]: modernization is based on the regular, constant and targeted use of human activity for the consistent coordination of the natural and social environment of a person. Industrialization as a strong, active, methodological aspect of modernization was substantiated by Apter D. [4]. Smelser N.J. [5] contributed to the practice of modernization, considering it as a complex of changes that change society through industrialization. Modernization is associated with continuous change, complex and multidimensional changes in various areas. Changes occur in the spheres at different rates, but constantly. Inglehart R. and C. Welzel [6] came to a similar conclusion that industrialization and post-industrialization are two phases of modernization. Modernization as social changes leading to economic and political progress in countries that become an example for the laggards, researches Bendix R. [7]. Przeworski A. and F. Limongi [8] have empirically reached a similar conclusion. Levy M.J. [9] found a positive relationship between the level of modernization and the level of energy use of machines in order to increase the effect.

The modernization literature focuses on leveraging technological breakthroughs. Modernization is a process that manifests itself in the adaptation of society to dramatically changing conditions due to scientific and technological progress. In just a couple of decades, the world has experienced several information technology revolutions. The premise of modernization is the progress of human knowledge, states Black C. [10]. Huntington S.P. [11] highlights the process of identity.

There is a clash between the backward and the modern. Modernization makes countries similar. Vago S. analyzes modernization as a process resulting in the transformation of a pre- 
industrial society into an industrial one [12]. The transformation is based on progressive technologies, an increase in the quality of factors of production, the continuity of the introduction of innovations, investments, an increase in the economic power of a nation. The Internet, electronic databases, digital technologies to enhance interaction, software are "weightless" knowledge products, Prateek G. concludes [13]. Tachau F. considers modernization to consists of the spread of technology, investment, and sustainable economic growth [14]. A question raised by Berger P.L. [15], consists in the technological transformation of the economy. Several authors, Macridis R.C., Brown B.E. [16], believe that a modernized society is characterized by the values of science, knowledge, results. The definitions of modernization directly link technology with the transformation of the economy.

Rustow D. [17] notes that modernization is characterized by cooperation between people, advanced technology, science, rationality, social justice. Eisenstadt S.N. [18] concluded that modernization is a specific civilization or a new type of civilization that ensures stability and development.

The variety of concepts that determine the economic content of modernization led to the need for their generalization. The terminological analysis carried out made it possible to build a hierarchy of concepts: "modernization" (basic concept), "human", "continuous changes", "industrialization", "progress", "process", "quality", "technologies", "investments", "economic growth," "development" (the resulting concept in the hierarchy). On its basis, it was concluded that the concept of "modernization of the economy", possessing the attributes of the concepts included in the hierarchy, comprehensively characterizes the following: society;

- the goal in the form of creating a progressive

- a task in the form of sustainable functioning of business structures;

- the basis in the form of human activity.

Based on the definition of the concept of modernization in the specialized literature and the highlighted qualitative characteristics, it can be concluded that modernization as an economic category is currently characterized by controversy. It can be seen from the analyzed scientific works that the concept of "modernization" aggregates categories such as innovation, effect, change, challenge, cooperation, processes, competitiveness, change, economic growth, technology, a new type of civilization. Analysis of the definitions of the term "modernization" showed that such a characteristic as "changes" is present in the above definitions $35.3 \%$, "economic growth, technology" $-47.1 \%$. These two characteristics of modernization account for $82.4 \%$ of the total number of analyzed terms.

In the Republic of Kazakhstan, one can identify these qualitative characteristics in the issue area under study.

Modernization of the domestic economy can be ensured through modernization programs based on the adoption of strategic decisions on the transformation of agriculture, industry, and enterprises.

Many countries, incl. Kazakhstan represent a modernizing society. It is distinguished by the ongoing research on the optimal path, integrating new in the economy, as well as in the agricultural sphere. The modern process is characterized by the complexity of modernization trends in the economy.

\section{Methodology}

The formulation and solution of the research problem involves the analysis of scientific sources in the field of studying the specifics and role of economic modernization, considering both global, national and regional trends of its development.

The methodology of the research is based on principles and methods that are universal in research. This is information analysis (to summarize the characteristics of state programs in the agricultural economy), comparison (to assess the effectiveness of the innovative transformation of agriculture), analysis and synthesis (to highlight the elements of agricultural modernization). These methods contributed to the achievement of the reliability and validity of the conclusions, the development of the main provisions, the provision of the logic of the study, the correspondence of the conclusions to the peculiarities of modern economic practice.

The logic of the study, as well as the chosen approach to the analysis and solution of the problems posed, reflect the author's view of the priority and internal interconnectedness of the processes of modernizing the agricultural economy, considering modern realities.

\section{Results and discussion}

The agro-industrial complex of Kazakhstan functions in the conditions of an intensifying competition in the world food market, digitalization of the world economy, and asymmetry of globalization processes. The domestic agroindustrial complex must adapt to these conditions, effectively using its advantages in the "area of arable land per capita," which is second in the world. In addition, Kazakhstan is a powerful exporter of strategic products: grain and flour with 
agricultural production carried out on $1,546,000$ hectares of irrigated land, while moisture-saving technologies are used on 210,400 hectares.

Assessment areas of modernization are crop production, livestock, rural development, land resources, innovation, and technology.

Comprehensive modernization of agriculture is necessary to ensure the food security of the Republic of Kazakhstan. Agricultural modernization is based on agricultural policies consistent with the UN Sustainable Development Goals and the FAO Strategic Objectives [19]. The vector of modern agricultural policy is the entry of Kazakhstan into the world market with agricultural products that meet international quality standards. Therefore, large-scale modernization and transition to an innovative model for the development of the domestic agro-industrial complex and smart farming are becoming a necessity.

The goal of modernizing the agrarian economy is the stable development of an innovative agricultural system adapted to the ongoing changes, providing a multiplying effect for the development of other industries, integration into the global arena as a competitive participant, and greening of production. The ultimate goal is the formation of a strong state that ensures a high level of well-being of the population.

Agricultural modernization tasks:

- transition from a source of raw material to an innovative model (start of a new model of the agricultural economy);

- high-tech accumulation and reproduction;

- the formation of a new quality of investment demand;

- building up ecological agriculture;

- inclusion of farmers into the world agri-food system, first of all, with products of high value added;

- Achieving appropriate levels of food safety standards;

- decrease in food imports;

- saving foreign exchange reserves;

- growth of the economy as a whole;

- growth of employment and quality of life of rural residents;

- ensuring the profitable functioning of agricultural business firms in the long term.

For a more detailed study of the modernization of agricultural production, let us consider its structural elements.
The state implements a course of minimal intervention in the economy (laissez faire, laissez passer), but in agricultural production, the economic policy being implemented has some peculiarities [20]. Centralized assistance is necessary for the industry under study, such as special state programs.

The impetus for agrarian modernization was given by the government financial assistance. The progressive fulfillment of the goals of modernizing domestic agriculture with the help of state programs is reflected in Table 1.

Table 1 shows that the programs are aimed at using advanced technologies, import substitution, promoting the export of agricultural products (in 2019 , exports were carried out to 72 countries) and competitiveness in international markets, as well as sustainable development of economic entities, ensuring the quality of life of the population, food security, and infrastructure content. The goals of the implemented state programs reflect the relationship between the modernization of agriculture and sustainable development of the economy, and meet the objectives of intensive and innovative growth to increase agricultural innovation potential, eliminate the gap between agricultural production and the food industry, inequality between the city and the countryside on the basis of infrastructural and socio-engineering arrangement of rural areas. The necessary resources for the implementation of the 10th program are provided in the amount of 2774630 million tenge, incl. KZT 1,740,100 million or $62.7 \%$ from the state budget, KZT 768,236 million or $27.7 \%$ from local budgets, and KZT 266,294 million or $9.6 \%$ from other sources. Financing of this program is 672.3 billion tenge larger, or $32.0 \%$, compared to the Program "Agribusiness-2017". Compared to the Program for the development of the agro-industrial complex for 2010-2014, it is 1738666 million tenge larger, which is $267.8 \%$. A significant part of the funds allocated within the framework of State programs are expenditures from the first-tier budget. Financing the directions of the State Program for the Development of the Agro-Industrial Complex of the Republic of Kazakhstan for 2017-2021 should increase the efficiency of the agricultural business by increasing labor productivity and exporting processed products. It can be argued that government programs are a financial platform for agricultural modernization. 
Table 1 - Characteristics of state programs for the development of the agro-industrial complex of the Republic of Kazakhstan

\begin{tabular}{|c|c|c|c|}
\hline № & The name of the program & $\begin{array}{l}\text { Program } \\
\text { implementation } \\
\text { period }\end{array}$ & Purpose of the program \\
\hline 1 & $\begin{array}{l}\text { Social and economic development } \\
\text { program «Auyl» }\end{array}$ & $\begin{array}{l}1991-1995 \text { and } \\
\text { for the period } \\
\text { up to } 2000\end{array}$ & $\begin{array}{l}\text { - the formation of a social infrastructure in the } \\
\text { countryside, corresponding to the modern period; } \\
\text { - improvement of comfortable conditions, provision } \\
\text { of utilities in full }\end{array}$ \\
\hline 2 & $\begin{array}{l}\text { Conceptual program for the develop- } \\
\text { ment of the agro-industrial complex }\end{array}$ & $\begin{array}{l}1993-1995 \text { and } \\
\text { up to } 2000\end{array}$ & $\begin{array}{l}\text { - scientifically grounded and stable trend of the } \\
\text { agro-industrial complex }\end{array}$ \\
\hline 3 & $\begin{array}{l}\text { Agricultural production development } \\
\text { program }\end{array}$ & $2000-2002$ & $\begin{array}{l}\text { - agroeconomic growth; } \\
\text { - increasing the competitiveness of manufactured } \\
\text { products; } \\
\text { - increase in production of strategic and demanded } \\
\text { types of agricultural products }\end{array}$ \\
\hline 4 & State agri-food program & $2003-2005$ & $\begin{array}{l}\text { - food security of Kazakhstan as an element of } \\
\text { national security; } \\
\text { - organization of competitive production }\end{array}$ \\
\hline 5 & $\begin{array}{l}\text { State program for the development of } \\
\text { rural areas }\end{array}$ & $2004-2010$ & $\begin{array}{l}\text { - creation of territories: 1) with a high level of } \\
\text { economic development; 2) with a developed } \\
\text { infrastructure; 3) with optimal settlement } \\
\text { - high standard of living }\end{array}$ \\
\hline 6 & $\begin{array}{l}\text { The concept of sustainable develop- } \\
\text { ment of the agro-industrial complex }\end{array}$ & $2006-2010$ & - industrialization, modernization development \\
\hline 7 & $\begin{array}{l}\text { The program of priority measures for } \\
\text { the implementation of the Concept of } \\
\text { sustainable development of the agro- } \\
\text { industrial complex of the Republic of } \\
\text { Kazakhstan }\end{array}$ & $2006-2010$ & $\begin{array}{l}\text { - the equilibrium state and financial stability of the } \\
\text { agro-industrial complex; } \\
\text { - an increase in the output of products per employee; } \\
\text { - stable revenue; } \\
\text { - development of national competitive advantages } \\
\text { of domestic products }\end{array}$ \\
\hline 8 & $\begin{array}{l}\text { Agro-industrial complex development } \\
\text { program }\end{array}$ & $2010-2014$ & $\begin{array}{l}\text { - the formation of a competitive agro-industrial } \\
\text { complex; } \\
\text { - strengthening food security; } \\
\text { - expansion of export opportunities }\end{array}$ \\
\hline 9 & $\begin{array}{l}\text { Program for the development } \\
\text { of the agro-industrial complex } \\
\text { in the Republic of Kazakhstan } \\
\text { «Agrobusiness-2017» }\end{array}$ & $2013-2020$ & - increasing the competitiveness of rural producers \\
\hline 10 & $\begin{array}{l}\text { State program for the development } \\
\text { of the agro-industrial complex of the } \\
\text { Republic of Kazakhstan }\end{array}$ & $2017-2021$ & $\begin{array}{l}\text { - increase in products that are in demand in the } \\
\text { agricultural market }\end{array}$ \\
\hline
\end{tabular}

According to S.E. Alifanova, state programs are the subject of activation of modernization [21]. In the context of the coronavirus pandemic and changes in the budgetary landscape, the State Program affects the country's development, since it contains an investment-stimulating component, fulfills the tasks of the current budgetary policy, and due to the multiplier effect, there is an additional budgetary impulse [22]. The strategic development of the agro-industrial complex in Kazakhstan's regions is determined by the joint impact of innovative transformations in the technological development of the agricultural sector and the implementation of state programs aimed at financial, technological, technical support of multiple agricultural entities.
The optimum of industrial agricultural production and small agribusiness, the development of infrastructure and non-agricultural entrepreneurship are the main trends for increasing the social significance of the development of rural areas [23]. Target trends in the development of rural areas in the national interests are inseparable from an increase in their investment potential, which ensures comfortable living and employment, further social and environmental development, a decrease in the outflow of labor resources, an increase in the well-being of the rural population, the diversification of the rural economy through the creation in rural localities of various entrepreneurial activities. Diagnostics of the indicator of sustainable development of rural areas 
is based on the demographic and environmental situation, quality of life, agricultural, nonagricultural, alternative activities), housing stock, infrastructure (social, transport, engineering, information, communications), rural labor market.
Consider the current state of domestic agricultural production. The weight of the macroeconomic indicator "the share of GDP of agricultural products in the GDP of the Republic of Kazakhstan" is shown in Table 2.

Table 2 - Production volumes of the Republic of Kazakhstan, billion tenge

\begin{tabular}{|l|c|c|c|c|c|c|}
\hline \multicolumn{1}{|c|}{ Indicator } & 2015 year & 2016 year & 2017 year & 2018 year & 2019 year & $\begin{array}{c}2019 \text { year } \\
\text { to 2015 } \\
\text { year., } \%\end{array}$ \\
\hline Gross domestic product & 40884,1 & 46971,1 & 54378,9 & 61819,6 & 68956,4 & 168,7 \\
\hline Industrial production volume & 14903,1 & 19026,8 & 22790,2 & 27218,1 & 29103,0 & 195,3 \\
\hline Gross agricultural output & 3307,0 & 3684,4 & 4070,9 & 4474,0 & 5151,1 & 155,8 \\
\hline gross crop production & 1825,2 & 2047,6 & 2249,2 & 2411,5 & 2817,7 & 154,4 \\
\hline gross livestock production & 1469,9 & 1621,5 & 1810,9 & 2050,4 & 2319,5 & 157,8 \\
\hline
\end{tabular}

Note: Committee on Statistics of the Ministry of National Economy of the Republic of Kazakhstan https://stat.gov. $\mathrm{kz} /$

Analysis of the data in Table 2 revealed that in the reporting year, the agricultural output accounted for $7.5 \%$ of the total GDP of the Republic of Kazakhstan (8.1\% in 2015). During the study period, the indicator increased by 1844.1 billion tenge, or $55.8 \%$, on average over the years, the segment of agricultural production in GDP over the past 5 years has increased by $10-15 \%$. Sectoral parity between the two branches of crop and livestock production has not been achieved; this trend does not contradict the experience of countries with developed agriculture (crop production in the EU accounts for $56 \%$, in the USA 53\%) [24]. The crop sector dominates by $21.5 \%$ with a simultaneous increase in the share of livestock by years from 1469.9 billion tenge in 2015 to 2319.5 billion tenge in 2019 (an increase of $57.8 \%$ ). As the movement of the livestock production index in the Republic of Kazakhstan shows, in recent years there has been a dynamic of growth in production volumes - 2019 13.1\%, 2018 $13.2 \%, 201711.7 \%, 201610.3 \%$... Over the past year, there has been a trend towards growth in crop production - $201916.8 \%, 2018$ 7.2\%, 2017 9.8\%, 201612.2

John W. Mellor notes that rapid agricultural growth accelerates economic transformation into a modern economy, and agricultural modernization is the main tool for eliminating poverty in rural areas [25].

The development of agricultural production, an increase in its productivity is associated with the use of fertilizers, since fertilizers as a factor in agriculture contributes to an increase in the yield of agricultural crops, the productivity of crop rotation.

Table 3 - Use of fertilizers for agricultural crops by agricultural enterprises in the Republic of Kazakhstan

\begin{tabular}{|l|c|c|c|c|c|c|}
\hline \multicolumn{1}{|c|}{ Indicator } & 2015 year & 2016 year & 2017 year & 2018 year & 2019 year & $\begin{array}{c}2019 \text { year } \\
\text { to } 2015 \\
\text { year., } \%\end{array}$ \\
\hline $\begin{array}{l}\text { Area fertilized with mineral } \\
\text { fertilizers, thousand hectares }\end{array}$ & 1149,8 & 1303,1 & 1634,5 & 1967,8 & 2291,8 & 199,3 \\
\hline $\begin{array}{l}\text { Area fertilized with organic } \\
\text { fertilizers, thousand hectares }\end{array}$ & 39,4 & 61,0 & 91,6 & 83,4 & 78,7 & 199,7 \\
\hline $\begin{array}{l}\text { Application of mineral } \\
\text { fertilizers, thousand tons }\end{array}$ & 60,2 & 63,3 & 104,4 & 105,0 & 67,8 & 112,6 \\
\hline $\begin{array}{l}\text { Application of organic } \\
\text { fertilizers, thousand tons }\end{array}$ & 176,2 & 334,8 & 463,6 & 424,0 & 361,2 & 205,0 \\
\hline Sown area, mln.ha & 21,0 & 21,5 & 21,8 & 21,9 & 22,1 & 105,2 \\
\hline $\begin{array}{l}\text { Sown area of cereals (including } \\
\text { rice) and legumes, million } \\
\text { hectares }\end{array}$ & 15,0 & 15,4 & 15,4 & 15,1 & 15,4 & 102,7 \\
\hline Sown area of wheat, mln.ha & 11,8 & 12,4 & 12,0 & 11,4 & 11,4 & 96,7 \\
\hline
\end{tabular}

Note: Committee on Statistics of the Ministry of National Economy of the Republic of Kazakhstan https://stat.gov. $\mathrm{kz} /$ 
In modern technologies for the cultivation of agricultural crops, the optimal ratio of mineral and organic fertilizers or certain types of mineral fertilizers is used to preserve and reproduce soil fertility and increase productivity. On average, in Kazakhstan for 2015-2019, 1669400 hectares were fertilized annually with mineral fertilizers, 70 834 hectares with organic fertilizers, 80.1 thousand tons of mineral fertilizers were applied with an annual demand of 1.0 million tons, 351.2 thousand tons of organic fertilizers with an annual demand of 110 million tons, which means that fertilizers are used in limited quantities. In 2019, the area of agricultural land fertilized with mineral fertilizers amounted to 2,291.8 thousand hectares, an increase in comparison with 2015 of 11422.0 thousand hectares or $99.3 \%$. In terms of the area fertilized with mineral fertilizers, the leaders are the North Kazakhstan region (884.5 thousand hectares or $38.6 \%$ ), Kostanay region (559.7 thousand hectares or $24.4 \%$ ), Akmola region (492.8 thousand hectares or $21.5 \%$ ), the total share is $84.5 \%$. Most of all, mineral fertilizers were introduced in the North Kazakhstan region (29.7 thousand tons or $43.8 \%$ ), Akmola region (9.3 thousand tons or $13.7 \%$ ), these two regions account for $57.5 \%$. The share of the area treated with mineral fertilizers in the total sown area of agricultural land in 2019 is $10.4 \%$. In 2020, the number of subsidies for mineral fertilizers was increased to 26 billion tenge (2019 - 19 billion tenge). The area fertilized with organic fertilizers in the reporting year amounted to 78.7 thousand hectares, an increase in comparison with 2015 of 39.3 thousand hectares or $99.7 \%$. Only $0.3 \%$ of the land is fertilized with organic matter. Most fertilization with organic matter happened in the Akmola region (31.7 thousand hectares or $40.3 \%$ ), North Kazakhstan region (17.7 thousand hectares or $22.5 \%$ ), the total share is $62.8 \%$. Most of all, organic fertilizers were introduced in the
North Kazakhstan region (68.4 thousand tons or $18.9 \%$ ), Aktobe region (54.5 thousand tons or $15.1 \%$ ), East Kazakhstan region (54.2 thousand tons or $15.0 \%$ ) - these three regions account for $49.0 \%$. There is a shortage of organic fertilizers at an application rate of 5 tons / ha. In Kazakhstan, farms to produce vermicompost began to develop in the North Kazakhstan, Karaganda, Kostanay, Turkestan, Pavlodar regions. The share of the cultivated area with fertilizers in the total sown area of agricultural land in 201 is $10.7 \%$. Despite the fact that Kazakhstan is the leader in the production and export of grain crops, their productivity is at a low level, and the leading positions are provided to a greater extent due to a significant land fund. The modernizing of agricultural production makes a demand for technologies of differentiated application of liquid and solid fertilizers in the field and prescribing maps. To modernize agriculture, it is important to use smart fertilizers (you can control their impact on nature), which are included by Scientific American and the World Economic Forum among the important and useful discoveries of 2019. Effectively applying stabilized fertilizers (substances with controlled release of nutrients) help to reduce carbon dioxide emissions, prevent land degradation, increase yields.

According to the official data of statistical observations as of 01.01.2020 in the Republic of Kazakhstan, these are subjects of modernization in agriculture: legal entities represented by agricultural cooperatives, joint-stock companies, economic partnerships - 17403 units, peasant (farm) farms - 219449 units, individual entrepreneurs - 30195 units, households - 1638561 units.

Labor potential enhances the possibilities of modernization and the implementation of an innovative model in the industry under study. This is facilitated by state regulation of the agrarian labor market [26].

Table 4 - Rural labor resources of the Republic of Kazakhstan, thousand people

\begin{tabular}{|l|c|c|c|c|c|c|}
\hline \multicolumn{1}{|c|}{ Indicator } & 2015 year & 2016 year & 2017 year & 2018 year & 2019 year & $\begin{array}{c}2019 \text { year to } \\
2015 \text { year., } \\
\%\end{array}$ \\
\hline $\begin{array}{l}\text { Labor resources - total in the Republic } \\
\text { of Kazakhstan }\end{array}$ & 8433,3 & 8553,3 & 8585,2 & 8695,0 & 8780,8 & 104,1 \\
\hline Rural labor force & 3769,1 & 3846,6 & 3840,1 & 3861,4 & 3830,7 & 101,6 \\
\hline Rural Employed Population & 3574,9 & 3662,7 & 3653,1 & 3677,5 & 3648,8 & 102,1 \\
\hline $\begin{array}{l}\text { employment rate of the rural population } \\
\text { to the level of labor force, \% }\end{array}$ & 94,8 & 95,2 & 95,1 & 95,2 & 95,3 & - \\
\hline Rural Employed Population & 2225,9 & 2240,9 & 2325,7 & 2385,7 & 2369,2 & 106,4 \\
\hline $\begin{array}{l}\text { share in the employed rural population, } \\
\%\end{array}$ & 62,3 & 61,2 & 63,7 & 64,9 & 64,9 & - \\
\hline Rural self-employed population & 1349,0 & 1421,8 & 1327,4 & 1291,8 & 1279,6 & 94,8 \\
\hline $\begin{array}{l}\text { share in the employed rural population, } \\
\%\end{array}$ & 37,7 & 38,8 & 36,3 & 35,1 & 35,1 & - \\
\hline
\end{tabular}

Note: Committee on Statistics of the Ministry of National Economy of the Republic of Kazakhstan https://stat.gov. $\mathrm{kz} /$

Экономика: стратегия и практика. Т. 16, № 3, 2021 / Economics: the strategy and practice Vol. 16. No 3, 2021 
The agriculture of the Republic of Kazakhstan in 2019 employs 3,830.7 thousand people, or $43.6 \%$ of the population employed in the country's economy. The labor force in rural areas during the study period increased by $1.6 \%$. In general, in agriculture, an increase in the number of employed rural residents in the economy of Kazakhstan from 2015 to 2019 is at $2.1 \%$. When comparing 2019 with 2018, there is a slight decrease in all indicators in agriculture in the reporting period.

In 2019, labor productivity in agriculture of the Republic of Kazakhstan amounted to 6,000 US dollars (2.4 million tenge), which is significantly lower than the indicator in South Africa of 11,500 US dollars, Turkey of 15,700 US dollars, Russian Federation of 17,000 US dollars, US 90,000. Labor productivity in the agricultural sector of Kazakhstan is low not only in comparison with the above countries (in the USA this indicator is 15 times higher, in the Russian Federation it is 2.8 times, in Turkey it is 2.6 times, in South Africa 1.9 times higher), and it is low against the background of the share of the employed and the large rural population (41.5\% in 2019). Low labor productivity does not allow increasing the efficiency of production and processing of agricultural products, value added and profitability of agricultural entrepreneurship.

Progress and reform are the foundations of modern modernization theory. In various areas economic, technological, organizational, cultural - changes are simultaneously taking place. These changes are positive. Currently, the general trend is the modernization of the agricultural economy. It is associated with innovations that are introduced by economic entities. The agrarian economy is moving to a new level. Modernization of the agrarian economy provides the basis for the transition to an innovative economy. The economics of the introduction of new technologies in agriculture, induced innovations were studied by scientists Sunding D., Zilberman D. [27]. The starting point for the modernization of agriculture is the accelerated technical and technological renewal of the industry. We agree with the scientists justifying frontal modernization. Frontal modernization covers all levels of the economy: nano-modernization $\rightarrow$ micromodernization $\rightarrow$ macromodernization $\rightarrow$ mega-modernization. Whereas the focal modernization model has stages:

- catch-up development. Import of technologies, accounting for global macro trends in agriculture and international trade, government support;

- breakthrough development. Investment projects, achievement of leadership.

Concentration of efforts in one industry negates the development of others. The model of the economy, focused on breakthrough projects, breakthrough industries, is inferior to the model aimed at improving the conditions for the development of the economy as a whole.

In 2019, 7,479,879.6 million tenge were invested in rural areas, of which 3,902,983.5 million tenge or $52.3 \%$ in the Atyrau region, the second place is occupied by the West Kazakhstan region with $479,305.4$ million tenge or $6.4 \%$. There is a very large gap between the 1st and the 2nd place for investment in rural areas, amounting to $45.9 \%$.

Modernization changes in agriculture are associated with the technical and technological base. This involves analyzing trends in the dynamics of fixed assets. Fixed assets are the object of modernization, and depending on their condition, they are a stimulating or deterrent factor in the technological modernization of the industry under study.

The technological structure of investments in fixed assets in rural areas is as follows: construction and overhaul of buildings and structures with $3,009,567.1$ million tenge or $40.2 \%$; machinery, equipment, vehicles, tools and their overhaul with $1,944,118,7$ million tenge or $26.0 \%$; and other costs in the volume of investments in fixed assets with 2526193.8 million tenge or $33.8 \%$. The indicators show the priority of investments in buildings, structures, in materialized technologies - machines, equipment $(66.2 \%)$ over non-material ones - patents, inventions, results of scientific research. The data of the Committee on Statistics of the Ministry of Education and Science of the Republic of Kazakhstan do not allow analyzing the direction of investment in materialized technologies: what share of funds is directed to extensive growth (expansion), and what share is directed to innovative development (modernization of technological processes).

Investments in fixed assets in rural areas by sources of financing in 2019 at the expense of: the republican budget of 299111.9 million tenge or $4.0 \%$, the local budget of 174464.5 million tenge or $2.3 \%$, and own resources amounting to 6486 475.0 million tenge or $86.7 \%$, bank loans of 73 125.3 million tenge or $1.0 \%$, and other borrowed funds of 454703.0 million tenge or $6.0 \%$.

The reproduction of fixed capital on an innovative basis in agriculture is associated with investments in the material and technical base, which ensures the implementation of agrotechnical processes in agriculture at the optimum time, in animal husbandry, an increase in the productivity of animals and birds. In the agro-industrial complex, a tendency can be noted that the ownership of agricultural machinery is giving way to rent and leasing, and in the modern period the market is being transformed in the direction of time-sharing of machinery. 
In 2019, 442.30 billion tenge was invested in agriculture, and 454.2 billion tenge in 2020 .

Agriculture, with its development potential, in the reporting year showed low attractiveness for foreign investors. The dynamics of foreign investments in the agricultural sector can be assessed as stagnating. The gross inflow of foreign direct investment (FDI) in agriculture, forestry and fisheries amounted to 71.8 million USD in 2015, 50.1 million USD in 2016, 27.5 million USD in 2017, 12.1 million USD in 2018, and 10.1 million USD in 2019. Capital investments for 2015-2019 decreased by $85.9 \%$. There was an investment pause. The stressors of 2020 are an inappropriate investment environment. The unsustainable investment component is associated with risks and challenges affecting agricultural business. This is also the acceleration of food inflation, the reason for which is the increase in the cost of imports due to the depreciation of the tenge, which leads to an increase in costs.

Agricultural production has gone through advanced technology stages:

- automation;

- digitalization;

- informatization.

The modern stage is the introduction of digital technologies or the agrarian revolution 4.0 [28].

It can be concluded that the agricultural industry is in a state of continuous evolution.

Manzhosova I.B. argues that the goal of modernizing agriculture is bringing agriculture to the standards of the digital economy [29]. In the Republic of Kazakhstan, a digitalization program was approved - e-agro-industrial complex, the State Program - Digital Kazakhstan - highlighting directions of digitalization of rural production. These include an increase in productivity, an increase in output per worker, food security, which contributes to strengthening the competitiveness of the national economy. The launch of the Digital Kazakhstan program has raised the digital agenda to the state level.

In agriculture in 2019, according to official data, digitalization brought an economic effect of 2.5 billion tenge. Digitalization of land relations is under way [30]. Electronic field maps, navigation systems, telematics are used in the attachments of seeding complexes, combines, an electronic system for feeding and receiving data on the weight of animals, milking machines with software, and robotic feed pushes. Forty-nine farms in 2019 introduced digital technologies (and this is only $0.02 \%$ of the total number of farms, while in the United States almost half of the farms have implemented digital technologies): 28 farms in precision agriculture (LLP "Naidorovskoe"), 21 farms in dairy (Rodina LLP, Bayserke Agro LLP) and meat animal husbandry (Terra LLP, Meat Industry LLP). In accordance with the e-APK program until 2020, an indicator was set for the creation of 20 digital farms, 4,000 advanced farms. Despite the significant lag from the planned indicator, it can be argued that the quality component of agriculture is changing, the demand for digital technology in Kazakhstan is growing, the potential volume of the smart farming market is large, and digital technologies are used more.

Agricultural modernization based on the digital economy is a means of achieving other goals: financial, economic, social. The digitalization of the agricultural sector changes the organizational structure of the market, the sphere of exchange, the commodity structure, and reduces information asymmetry.

The Food and Agriculture Organization of the United Nations defines the following basic conditions that allow for high-quality transformations based on digitalization in the agricultural sector:

- infrastructure and connectivity. They are determined by such indicators as wireless and mobile Internet access, network coverage area, the number of cellular subscribers, the provision of electricity to agriculture;

- access to financial services;

- knowledge in the field of information and communication technologies, which is determined by the level of education;

- institutional support [31].

When implementing the strategy of modernization of agricultural production, it is essential to improve the quality of living standards of villagers, otherwise the modernization "leap" is impracticable. The agrarian industry is not only the production of crop and livestock products but also the vitality of the aul.

The country has adopted the Regional Development Program for 2020-2025 (financing 412.8 billion tenge), a special project "Auyl - E1 besigi" for 2020-2026. In accordance with the project, the modernization of the infrastructure of rural areas is envisaged in 3,477 villages:

- increasing the level of well-being of the rural population and improvement of the housing stock;

- construction of engineering systems of vital functions, streets;

- modernization of the road infrastructure of Kazakhstani auls, despite the fact that rural roads are low-intensity roads. Development of access roads to agricultural complexes, farms, agricultural processing facilities, socially significant facilities, elimination of transport gaps. For farmers, this means cost savings;

- an increase in the percentage of residential buildings, premises, complexes with access to all 
types of utilities (water supply, drainage, heating, bath, shower, hot water supply);

- provision of high-quality drinking water;

- gasification;

- improving the social infrastructure in the countryside through the reconstruction and construction of health care facilities, educational organizations, cultural and leisure facilities, sports facilities;

- uninterrupted supply of energy resources;

- creation of comfortable and environmentally friendly living conditions.

Based on the results of the author's study of modernization in the agricultural sector, we highlight the factors of modernization in the agriculture of the Republic of Kazakhstan.

Macroeconomic factors: policy;

- institutional - national legislation, state

- market - growth in demand for agricultural products, competition in the agricultural market, integration of farmers into the markets for export goods;

- technological - scientific and technological progress, technological innovation, expanding access to information, the use of e-commerce platforms, blockchain technology.

Microeconomic factors:
- investment - innovative nature of investments, sufficient and affordable financial resources,

- resource - agriculture is a resource industry, the sufficiency of resources for modernization;

- organizational - innovative agricultural insurance (based on weather indices).

The positive factors of the internal environment - the application of protectionist policies in relation to the domestic food market, agriculture on a contract basis as a means of involving small farmers in profitable food markets with high added value, the requirements for the safety and quality of fruits and vegetables put forward by supermarkets and exporters.

Positive factors of the external environment - population growth, trade liberalization, international economic integration.

Negative factors of the internal environment are the depreciation of the national currency, differences between urban and rural areas in terms of living standards, infrastructure, income, lack of agricultural personnel, a decrease in domestic breeding stock, a weak seed production system and an increasing dependence on imported seeds [32].

Negative factors of the external environment - sensitivity to fluctuations in commodity markets, higher prices for imports of agricultural machinery, mineral fertilizers, seeds, livestock.

Elements of agricultural modernization are reflected in Figure 1.

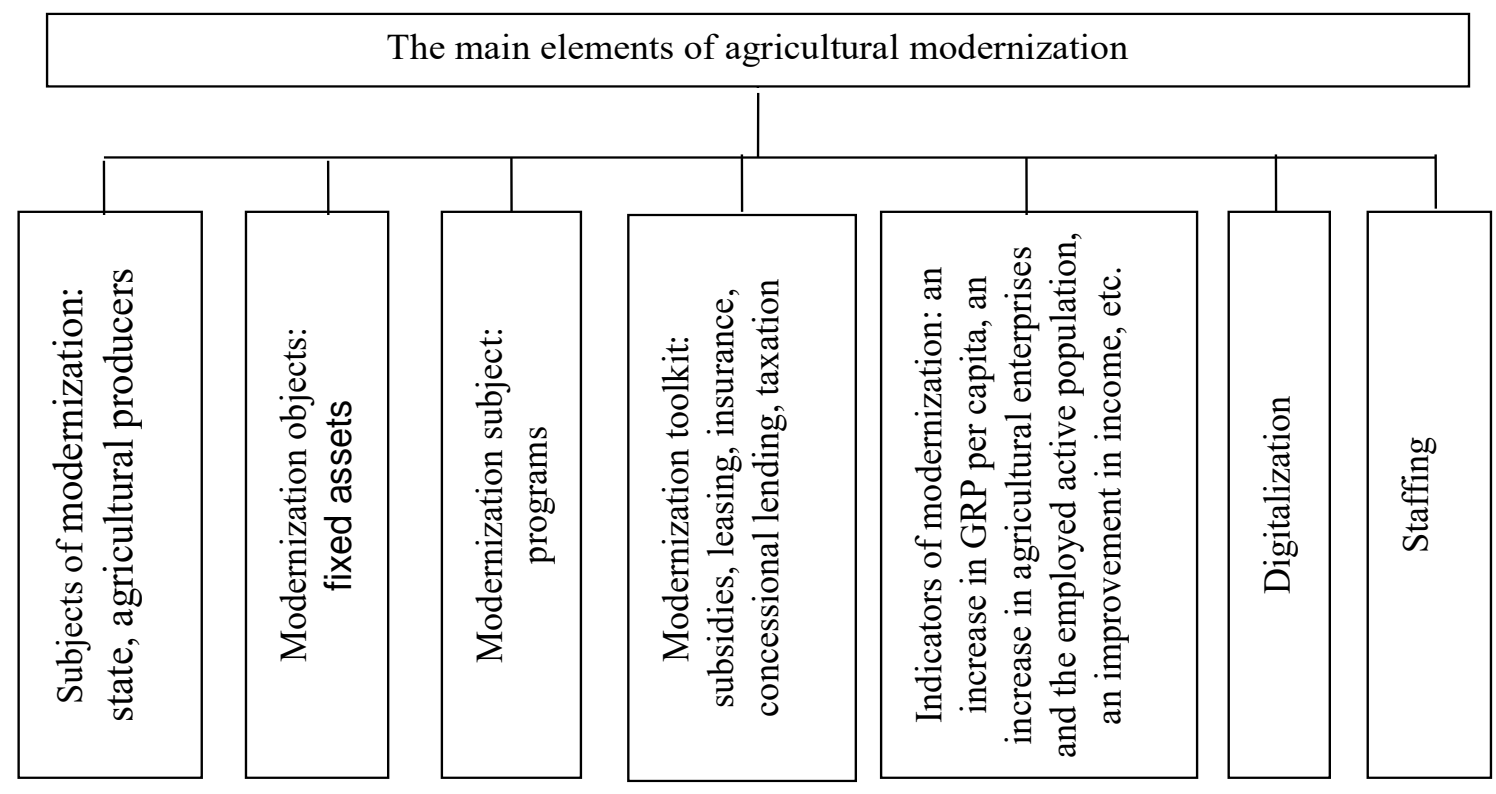

Figure 1 - Conceptual elements of modernization of the agricultural sector of the economy

Note: compiled by the authors. 
Subjects of modernization: the state (ministries, committees, agencies, departments, akimats), industry associations and unions (Grain Union of Kazakhstan, Union of Farmers of Kazakhstan, Union of Poultry Farmers, Association of Beet and Sugar Producers of the Republic of Kazakhstan, etc.), agricultural producers (peasant farms, individual entrepreneurs, households).

Objects of modernization: fixed assets (modernized buildings and structures, tools, world-class machinery and equipment system, computers, peripheral equipment - sensors and mobile vehicles).

The subject of modernization: programs (enterprises, state, strategic, targeted) that determine the long-term trajectories of the production and economic characteristics of agriculture.

Modernization tools: antitrust regulation, budget subsidies (there are Uniform subsidy rules in crop production, per hectare subsidies for priority crops, subsidies for seeds of domestic and foreign selection, herbicides, plant protection products), subsidies for the interest rate on loans, tax incentives in the form of financial incentives with multiplicative effect, tax rates, leasing of agricultural machinery and livestock, insurance, preferential lending, customs duties and tariffs, credit policy (preferential lending), agricultural consulting, agricultural parks, non-financial (institutional) measures. A new tool for the ROK is a results-based program (ERP) loan, i.e. funds that are disbursed to the borrower when agreed results are achieved. This financial instrument is used within the World Bank's 2021-2025 Sustainable
Livestock Development Project. The project reaches USD 500 million.

Indicators of modernization are the following: growth and growth of agricultural entities, employment in agriculture, profit, profitability, gross domestic product, productivity, technology, improved living standards and incomes of rural residents, quality of agricultural products, creation of new jobs, share of costs for innovation, the degree of mastering high technologies.

Digital Economy (Digital Agriculture): Contribution of Digitalization to Agroeconomic Growth Based on a Cost / Benefit Ratio. The modules "Personal account of an agricultural producer", "Smart farm", "Smart field", "Smart herd", "Smart greenhouse", "Smart processing", "Smart warehouse" are effectively used in practice.

Staffing: qualified personnel of mass professions in sufficient volume, improvement and enhancement of professional skills, the positive contribution of the labor factor to the growth rate of agriculture, the growth of entrepreneurs with digital dexterity, the creation of a continuous system of agricultural education. Since 2020, online consultations on agronomy and animal husbandry have been conducted by the Kazakh Agro Technical University. The following experience is used as a criterion: the Open Agrarian University "The Land of Knowledge" operates in the Russian Federation - it is a digital educational platform for distance learning for specialists of agricultural enterprises.

As a result of modernization, a structural transformation of the economy is carried out, including in agriculture.

\begin{tabular}{|c|c|c|c|c|}
\hline $\begin{array}{l}\text { Modern economy of the } \\
\text { Republic of Kazakhstan } \\
- \\
\mathrm{R}^{*}-\text { type of economy }\end{array}$ & $\longrightarrow$ & $\begin{array}{l}\text { Modernization of the } \\
\text { economy - a } \\
\text { progressive process of } \\
\text { qualitative } \\
\text { improvement of the }\end{array}$ & $\longrightarrow$ & $\begin{array}{c}\text { Target economy - } \\
\text { national reproduction } \\
\text { based on socio- } \\
\text { economic } \\
\text { development }\end{array}$ \\
\hline
\end{tabular}

$\mathrm{R}^{*}$ - type - the resource type

Figure 2 - Structural transformation of the economy

Note: compiled by the authors.

The modernization of agriculture is a popular direction, since despite the fact that the statement "agriculture is a driver, a locomotive of the economy" sounds axiomatic, the industry itself is not a high-tech industry at this point in time, does not demonstrate a significant increase in the profitability of production and product productivity.
At present, a strategy for modernizing agriculture has been formed, and the potential effects of modernizing the industry have been quantified. In agriculture, systemic transformations of a multidimensional nature are taking place. Modernization as an n-dimensional space encompasses such areas as the economy, production, technology, society and personnel. 


\section{Conclusion}

The main findings are as follows:

1. The study found that modernization has become the main characteristic of the processes taking place in all spheres of Kazakhstani society. Modernization is a priority of state policy. There is a relationship between ongoing agricultural modernization and sustainable development. The modernization of the agricultural economy plays a special role.

2. It is obvious that the Kazakh economy has not yet reached the innovative stage of development. Agro-ecological and climate-smart agricultural systems are in the stage of formation.

3. It was concluded that the modernization of the agricultural economy entails not only an innovative, but also a multiplier effect (transport infrastructure in rural areas of Kazakhstan, logistics, warehouse and wholesale distribution infrastructure, pre-sale preparation of agricultural products, storage facilities for agricultural products, special tractors of small and medium power, equipment for gardening, irrigation systems).

4. The study made it possible to determine that the economy as a whole and agriculture are consumers of innovations. The trend is the growth of innovations in agricultural technologies.

5 . Based on the analysis of the current state, we can conclude that there is a transition to an economy of an innovative type, which accelerates the transformation of agriculture into a modern one.

6. As a result, the modernization of Kazakhstani agriculture affects the reduction of negative externalities, the digital divide between urban and rural areas, increases the quality of life outside the city, ensures food security, rational use of natural resources, an increase in the profitability of farms, labor productivity without creating threats to agricultural animals, natural environment, introduction of environmentally friendly technologies.

7. It has been established that the modernization of the agrarian economy in Kazakhstan occurs through an increase in innovation, which contributes to competitiveness. Modernization of the agrarian economy, taking into account the global macro-trends in the agro-industrial complex, is a response to the modern challenge to meet the current and future development needs of the country. The dominant modernization of the agrarian economy is an uncontested version of agroeconomic growth, a necessary condition for the civilized transformation of Kazakhstan's agricultural business.

\section{References}

1 Veber, M. (2005). The Protestant Ethic and the Spirit of Capitalism. London and New York: Taylor \& Francis Group

2 Wucherpfennig, Yu., Deutsch, F. (2009). Modernization and Democracy: Theories and Evidence Revisited. Living Reviews in Democracy, 1, 1-9. http:// www.livingreviews.org/lrd-2009-4

3 Ward, R. (1963). Modern Political Systems: Eyrope. Edited by Roy C. Macridis and Robert E.Ward. Englewood Cliffs, N.J.: Prentise-Hall, Inc., 3, 724. https://doi.org/10.1017/S0003055400288205

4 Apter, D. (1965). The Politics of Modernization. Chicago: University of Chicago Press

5 Smelser, N.J., Haferkamp, H. (1992). Social Change and Modernity. University of California Press

6 Inglehart, R., Welzel, C. (2005). Modernization, Cultural Change and Democracy: The Human Development Sequence. Cambridge: Cambridge University Press

7 Bendix, R. (1977). Nation-Building and Citizenship: studies of our changing social order. Berkeley: University of California Press

8 Przeworski, A., Limongi, F. (1997). Modernization: Theories and Facts. World Politics, 2, 155-183. https://doi.org/10.1353/wp.1997.0004

9 Levy, Marion J.Jr. (1996). Modernization and the Structure of Societies: Aspects of Social Structure in Modernized and Non-Modernized Societies. Routledge

10 Black, C. (1975). The Dynamics of Modernization. A Study in Comparative History. New York, NY: Harper Colophon Books

11 Huntington, S.P. (1971). The change to change: modernization, development and politics. Comparative Politics, 3, 283-322. https://doi.org/10.2307/421470

12 Vago, S. (1989). Social Change. Englewood Cliffs, New Jersey: Prentice-Hall

13 Prateek, G. (2010). Modernization Theory. Oxford Research Encyclopedia, International Relations, 24. DOI: 10.1093/acrefore/9780190846626.013.266

14 Tachau, F. (1972). The Developing Nations: What Path to Modernization? New York, NY: Dodd, Mead

15 Berger, P.L. et al. (1973). The Homeless Mind: Modernization and Consciousness. Berger P.L., Berger B., Kellner H. New York, NY: Random House

16 Macridis, R.C., Brown, B.E. (1972). Comparative Politics: Notes and Readings. Homewood, IL: Dorsey

17 Rustow, D.A. (1967). World of Nations: Problems of Political Modernization. Washington DC, The Brookings Institute

18 Eisenstadt, S.N. (2007). Multiple Modernities A Paradigma of Cultural and Social Evolution. Gerhard Preyer Frankfurt am Main

19 Grigoruk V.V., Klimov E.V. (2016). Razvitie organicheskogo sel'skogo hozyajstva $\mathrm{V}$ mire i Kazahstane. FAO, Ankara

20 Pinstrup-Andersen. P., \& Watson, D.D. (2011). Food policy for developing countries: The role of government in global, national, and local food systems. Ithaca: Cornell University Press 
21 Alifanova S.E. (2015). Sovershenstvovanie organizatsionno-ekonomicheskogo mekhanizma tekhnologicheskoj modernizatsii sel'skogo hozyajstva. Volgograd

22 Tashenova S.D., Tuleubaeva M.K. (2019). Analiz promezhutochnyh rezul'tatov vypolneniya Gosudarstvennoj programmy industrial'noinnovattsionnogo razvitiya Respubliki Kazahstan // Ekonomika: strategiya i praktika, 3 (14), 85-98.

23 Myrzalıev B.S., Sabyr N.S., Mýrat A. (2020). Ustojchivoe razvitie sela - vazhnyj faktor obespecheniya sotsial'noj zashchishchennosti. // Ekonomika: strategiya i praktika, 1 (15), 37-52.

24 Kiselev S., Romashkin R. (2020). Razvitie sel'skogo hozyajstva v Evrazijskom ekonomicheskom soobshchestve: dostizheniya, metody i perspektivy // APK: ekonomika, upravlenie, 1, 74-90.

25 John W. Mellor (2017). Agricultural Development and Economic Transformation. Christopher Barrett Cornell University Ithaca, New York, USA
26 Abdildinova N.E. (2019). Sovershenstvovanie gosudarstvennogo regulirovaniya agrarnogo rynka truda (na primere Akmolinskoj oblasti) // Ekonomika: strategiya i praktika. 2 (14). 97-107.

27 Sunding D., Zilberman D. (2001). The agricultural innovation process: research and technology adoption in a changing agricultural sector. Handbook of Agricultural Economics, edition 1, vol. 1, chapter 4, 207-261.

28 Plotnikov A.V. (2019). Rol' tsifrovoj ekonomiki dlya agropromyshlennogo kompleksa // Moskovskij ekonomicheskij zhurnal, 7, 21-27.

29 Manzhosova I.B. (2019). Formirovanie strategii modernizatsii sel'skogo hozyajstva v usloviyah tsifrovoj ekonomiki. Stavropol'

$30 \mathrm{https}: / /$ primeminister.kz/

31 Trendov, M.N., Varas, S., Czen, M. (2019). Cifrovye tekhnologii na sluzhbe sel'skogo hozyajstva $i$ sel'skih rajonov. Spravochnyj dokument. Prodovol'stvennaya i sel'skohozyajstvennaya organizaciya Ob"edinennyh Nacij, Rim

32 Kurmanova, G.K., Suhanberdina, B.B., Urazova, B.A. (2020). Razvitie regional'nogo sel'skogo hozyajstva Respubliki Kazahstan. Problemy agrorynka, 3, 43-50. https://doi.org/10.46666/2020.2708-9991.05

\section{Information about the authors}

Gulnara K. Kurmanova - Candidate of Economic Sciences, Associate Professor of the Department of Accounting and Finance, West Kazakhstan Innovative-technological University, e-mail: gulnara.ru @, mail.ru. ORCID ID: https:// orcid.org/0000-0002-9052-2990

* Bibigul B. Sukhanberdina - Candidate of Economic Sciences, Associate Professor of the Department of Accounting and Finance, West Kazakhstan Innovative-technological University, e-mail: suhanb@mail.ru. ORCID ID: https:// orcid.org/0000-0002-8375-6350

Bakit A. Urazova - Master of Economics, Senior Lecturer, Department of Economics and Management West Kazakhstan Innovative-technological University, e-mail: kabdenova.68@mail.ru, ORCID ID: https://orcid.org/0000$\underline{0001-9284-3301}$

\section{Авторлар туралы мәліметтер}

Курманова Гульнара Кусаиновна - э.ғ.к., «Есеп және қаржы» кафедрасының доценті, Батыс Қазақстан инновациялық-технологиялық университеті, е-mail: gulnara.ru @, mail.ru, ORCID ID: https://orcid.org/0000$\underline{0002-9052-2990}$

*Суханбердина Бибигуль Батыркаировна - э.ғ.к., «Есеп және қаржы» кафедрасының доценті, Батыс Қазақстан инновациялық-технологиялық университеті, e-mail: suhanb@mail.ru. ORCID ID: https:/orcid. org/0000-0002-8375-6350

Уразова Бакит Адилгереевна - Экономика магистрі, экономика және менеджмент кафедрасының аға оқытушысы, Батыс Қазақстан инновациялық-технологиялық университеті, e-mail: kabdenova.68@mail.ru, ORCID ID: https://orcid.org/0000- 0001-9284-3301 


\section{Сведения об авторах}

Курманова Гульнара Кусаиновна - кандидат экономических наук, доцент кафедры Учет и финансы, Западно-Казахстанский инновационно-технологический университет, e-mail: gulnara.ru @, mail.ru. ORCID ID: https://orcid.org/0000-0002-9052-2990

* Суханбердина Бибигуль Батыркаировна - кандидат экономических наук, доцент кафедры Учет и финансы, Западно-Казахстанский инновационно-технологический университет, e-mail: suhanb@mail.ru. ORCID ID: https://orcid.org/0000-0002-8375-6350

Уразова Бакит Адилгереевна - магистр экономических наук, старший преподаватель кафедры Экономики и менеджмента. Западно-Казахстанский инновационно-технологический университет, е-mail: kabdenova.68@, mail.ru. ORCID ID: https://orcid.org/0000- 0001-9284-3301 